Old Dominion University ODU Digital Commons

Winter 2012

\title{
How Effective is the International Fuel Tax Agreement as a Multistate Tax Administration Model? A View From the States
}

Juita-Elena Yusuf

Old Dominion University, jyusuf@odu.edu

Lenahan O'Connell

Follow this and additional works at: https://digitalcommons.odu.edu/publicservice_pubs

Part of the Economic Policy Commons, Finance and Financial Management Commons, Taxation Commons, and the Transportation Commons

\section{Repository Citation}

Yusuf, Juita-Elena and O'Connell, Lenahan, "How Effective is the International Fuel Tax Agreement as a Multistate Tax Administration Model? A View From the States" (2012). School of Public Service Faculty Publications. 17.

https://digitalcommons.odu.edu/publicservice_pubs/17

\section{Original Publication Citation}

Yusuf, J.-E., \& O'Connell, L. (2012). How effective is the international fuel tax agreement as a multistate tax administration model? A view from the states. Journal of Public Budgeting, Accounting \& Financial Management, 24(4), 535-557.

This Article is brought to you for free and open access by the School of Public Service at ODU Digital Commons. It has been accepted for inclusion in School of Public Service Faculty Publications by an authorized administrator of ODU Digital Commons. For more information, please contact digitalcommons@odu.edu. 


\title{
HOW EFFECTIVE IS THE INTERNATIONAL FUEL TAX AGREEMENT AS A MULTISTATE TAX ADMINISTRATION MODEL? A VIEW FROM THE STATES
}

\author{
Juita-Elena (Wie) Yusuf and Lenahan O'Connell*
}

\begin{abstract}
The International Fuel Tax Agreement (IFTA) was established to reduce the complexities of reporting, allocating, and collecting diesel fuel taxes from interstate commercial carriers operating in multiple jurisdictions. This paper examines IFTA's effectiveness as a multistate tax administration model from the perspective of the states. We identify three criteria of effectiveness and use a survey of IFTA officials in the member states and provinces as well as additional data provided by IFTA, Inc to assess IFTA's effectiveness. We conclude that (1) IFTA promotes inter-jurisdictional cooperation and revenue transfers; (2) carriers do not locate disproportionately in low tax jurisdictions; and (3) IFTA's audit system, which relies on carrier record-keeping, may not be effectively preventing tax evasion.
\end{abstract}

\section{INTRODUCTION}

This study focuses on the International Fuel Tax Agreement (IFTA) as a system used to collect fuel tax payments from commercial trucking firms operating in more than one state or province. With the exception of Oregon, 47 of the 48 contiguous states and all 10 Canadian provinces levy a tax on the fuel-mostly diesel-used by

* Juita-Elena (Wie) Yusuf, Ph.D., is an Assistant Professor, Department of Urban Studies and Public Administration, Old Dominion University. Her research interests are in public budgeting and financial management, with a particular interest in transportation finance, and transparency, accountability and public participation. Lenahan O'Connell, Ph.D., is a Senior Research Associate, Kentucky Transportation Center. His research areas are transportation policy, finance and planning, mechanisms for accountability, and smart growth policy.

Copyright $\odot 2012$ by PrAcademics Press 
interstate commercial carriers, a tax customarily paid at the retail pump or wholesale rack upon purchase. These taxes provide a substantial share of transportation revenue in each of the states and provinces. The collection of diesel fuel taxes from interstate commercial carriers is difficult for a variety of reasons. First, tax rates per gallon as well as registration fees vary across the states and provinces. Second, the application of motor fuel taxes also varies. For example, fuel used for farming or construction and fuel sold to Native Americans on their reservations may or may not be taxed, depending on individual state policies.

The year 2011 marked the twenty-year anniversary of the establishment of IFTA. The U.S. Congress was also scheduled to renew the federal transportation reauthorization legislation in 2011. It is timely and appropriate, therefore to revisit IFTA - which was created through the landmark federal transportation legislation of the 1991 Intermodal Surface Transportation Efficiency Act (ISTEA) - and assess IFTA's effectiveness as a multijurisdictional tax administration model for the motor fuel tax.

Examination of IFTA's effectiveness as a multijurisdictional tax model will also have implications for other taxes that require coordination across multiple jurisdictions. The economic landscape is increasingly dominated by multi-state and multi-national businesses and corporations, but the states are often restricted in their ability to collect income taxes or sales taxes from such activities that cross interstate boundaries. IFTA is a system that administers motor fuel tax activities across not only the American states but also the Canadian provinces. Better understanding of IFTA's effectiveness and the mechanisms that contribute to effectiveness may contribute to different ways of thinking about other multijurisdictional taxes such as the corporate income tax and sales tax.

Several studies concluded that IFTA is successfully coordinating the collection of the diesel fuel tax. Pitcher (2001), for instance, concluded that IFTA successfully addressed the problem of nonuniformity in state tax requirements that had plagued the trucking industry for decades. In his assessment, IFTA "has been a remarkable success. It has preserved for the states the viability of a highly problematic but important source of highway revenue, and it has removed from a key national industry much of a paperwork and tax compliance burden...that prior to ISTEA was estimated at $\$ 750$ 
million a year" (p. 891). Studies by Denison and Facer (2005) and Griffin et al. (1994) reached similar conclusions. However, these studies did not address the issue of tax evasion related to the core challenge facing fuel tax collection-ensuring that taxes are paid in proportion to the miles driven in each jurisdiction in which a carrier operates.

To ensure proportional payment, commercial drivers are required to keep elaborate and accurate records on miles driven and fuel purchased (and fuel tax paid) in each state or province. Since carriers pay taxes at the pump, it is necessary to reconcile the differences between (1) what each carrier has already paid in taxes to each state, and (2) the total tax the carrier either owes a particular state or what is owed by that state to the carrier. For instance, a driver who buys fuel in a low tax state and drives in a high tax state will owe taxes to the state where most of the driving occurred. This can produce a strong temptation to conceal information on the miles driven in high tax states to avoid paying more taxes.

This paper looks at IFTA's effectiveness from the point of view of the states. It surveys the officials responsible for collecting fuel taxes and examines additional data relevant to assessing IFTA's effectiveness-including prevention of tax evasion, a topic not covered in the previous research on IFTA's effectiveness. We begin with a brief discussion of some perennial issues confronting tax collection and note their relevance to the collection of diesel taxes under IFTA. We then provide a short history of IFTA, followed by an overview of IFTA, including its structure and governance. We then discuss IFTA's approach to reducing fuel tax evasion in more detail. After describing the survey and presenting the findings, we conclude that IFTA appears to be effectively coordinating inter-jurisdictional revenue collections and transfers. However, poor record-keeping by carriers appears to be widespread and undermining compliance. Fuel tax collection could be strengthened, therefore, with additional auditing and stronger penalties for inaccurate records.

\section{SYSTEMIC ISSUES CONFRONTING FUEL TAX COLLECTION}

An effective system for collecting taxes has to address the seven core functions of tax collection, which are (1) taxpayer registration and service; (2) the declaration of assessment; (3) revenue and taxpayer accounting; (4) delinquency control; (5) audit; (6) 
enforcement; and (7) taxpayer appeal or protest. Under IFTA, taxpayer registration and service is rather transparent, as it occurs when vehicles are registered. At that juncture, carriers are informed of (and appear to fully understand) their obligation to keep accurate records of miles driven and taxes paid in each jurisdiction and pay taxes in proportion to the miles driven in the jurisdiction at the fuel tax rate in that jurisdiction. Interstate commercial carriers then compute their fuel tax assessment for each state given the amount of fuel taxes they have already paid.

Clearly, IFTA is a taxpayer active system of tax collection. Such collection systems "privatize much of the collection effort, that is, impose much of the collection responsibility on the private taxpayer" (Mikesell, 2007, p. 493). Income tax is the preeminent example of an active system calling for taxpayer record-keeping. Active systems reduce the cost to government of administering the collection effort, but on the downside, they expose the system to three sources of taxpayer error: (1) computational accident or inadvertent mistake; (2) confusion about the legal requirements; and (3) deliberate efforts to evade by falsifying records.

Each type of tax system, especially a taxpayer active system, requires a structure for enforcement in which delinquencies are detected and evasion sanctioned. This requires auditing of taxpayer activities and records. In a well-constructed system of audit and enforcement, the induced impact on voluntary tax payment, should be many times greater than the direct collections arising from the audit (Mikesell, 2007). This desired effect could manifest itself in auditors finding low rates of tax avoidance.

There are two primary tactics for increasing the returns from enforcement audits: (1) auditing a relatively large percentage of taxpayers each year; and (2) targeting the firms most likely to engage in the largest underpayments of taxes. Most tax administrators employ both but emphasize one more than the other depending on the circumstances. Thus, for instance, in regard to the state sales tax, Due and Mikesell (1994) stated that the annual auditing of three percent of taxpayers is the consensus ideal. The Internal Revenue Service, in contrast, relies more on the strategy of targeting wealthier taxpayers for audits.

To ensure compliance, IFTA requires state officials to audit three percent of the carriers registered in their state. This involves a review 
of their records to determine underpayment of taxes. When delinquencies are discovered, carriers must pay the additional assessment. Penalties are possible for underpayment; but may not be assessed when the carrier can claim inadvertent error related to the complexity of record keeping for taxes paid in specific jurisdictions.

IFTA's reliance on taxpayer record-keeping is a potential liability. Carriers can benefit from poor record-keeping as well as from deliberate misallocation of miles driven to low tax states. Moreover, an audit percentage of three percent of carriers may not be sufficient to encourage more accurate record-keeping.

As this discussion illustrates, coordination of reporting, and payment of tax assessment across the multiple jurisdictions, auditing of taxpayers, and enforcement of taxpayer compliance are all very critical elements of IFTA's effectiveness. All three will be incorporated into our assessment of how effective IFTA is from the state's perspective.

\section{BACKGROUND AND OVERVIEW OF IFTA}

\section{A Brief History of IFTA}

Before the development of IFTA, carriers faced a complex and costly fuel tax environment. Each state required each carrier that traveled in it to file a fuel use report. As described by Pitcher (2001), "[t]hese had different formats, different due dates, different methods of calculating the tax due, different rates of interest for underpaid liabilities, and different requirements for receipts and other records that needed to accompany a return" (p. 888). In addition, the states differed in regard to their definitions of taxable vehicles and imposed varying fees for different types of vehicles.

Carriers complained of excessive expense in time and money in trying to comply with the various state requirements. These expenses grew with the deregulation of the trucking industry and the attendant expansion of interstate trucking in the 1980s. In response, groups representing the industry drafted legislation to create a base state system that would simplify compliance. Thus began the journey to develop IFTA as we know it today. 
In 1991, Congress passed the Intermodal Surface Transportation Efficiency Act (ISTEA). ISTEA authorized the Federal Highway Administration (FHWA) to fund a working group to assist with the development of IFTA. At that time, while several states had cooperative agreements concerning the collection and allocation of fuel taxes, most states did not participate in these agreements.

ISTEA established incentives for states to join IFTA. "[A]fter September 20, 1996 no State shall establish, maintain or enforce any law or regulation which has fuel use tax reporting requirements (including tax reporting) which are not in conformity with the International Fuel Tax Agreement" (Intermodal Surface Transportation Efficiency Act, 1991). It is noteworthy that ISTEA did not require states to join IFTA. Yet, the incentives were sufficient to encourage participation in IFTA and today all 48 contiguous states and 10 Canadian provinces are members. ${ }^{1}$

The trucking industry, which was involved in the creation of IFTA, supports the IFTA system. Griffin et al. (1994), who surveyed commercial vehicle owners in FHWA Region 8, found that even in its formative years, IFTA was positively perceived by commercial carriers, who identified three benefits of IFTA. ${ }^{2}$ First, it reduced the amount of paperwork needed to comply with states' fuel tax reporting requirements. Second, it provided for a quicker tax reporting process. Third, IFTA introduced an improved audit experience. Overall, their findings indicated "a strong endorsement by the [motor carrier] industry of how the program is run" (Griffin et al., 1994, p. 17).

With industry involvement in its design, it is unsurprising that trucking firms are pleased with IFTA. The states, however, have other objectives, the foremost of which is revenue collection and allocation.

\section{How IFTA Works}

IFTA has three core provisions, statutorily authorized by ISTEA. These are (1) the base jurisdiction concept; (2) retention of each jurisdiction's sovereign authority to determine tax rates, exemptions and exercise other substantive tax authority; and (3) a uniform definition of the vehicles to which IFTA applies. 
Under the base jurisdiction concept, a carrier chooses a base and files its quarterly fuel use tax reports to that jurisdiction alone. The flow of payments and the reconciliation process under IFTA is outlined in Figure 1 . The base state shoulders the responsibility of reconciling tax payments among the jurisdictions. It does so by gathering the requisite information on travel miles and payments in each jurisdiction. Each carrier reports its travel miles, fuel use and fuel taxes paid in all member jurisdictions and then pays the net tax due or receives a net tax credit or sometimes a refund. The base state then distributes to the other jurisdictions in which the carrier

FIGURE 1

The Flow of Information and Fuel Tax Payments/Credits under the IFTA Reconciliation System

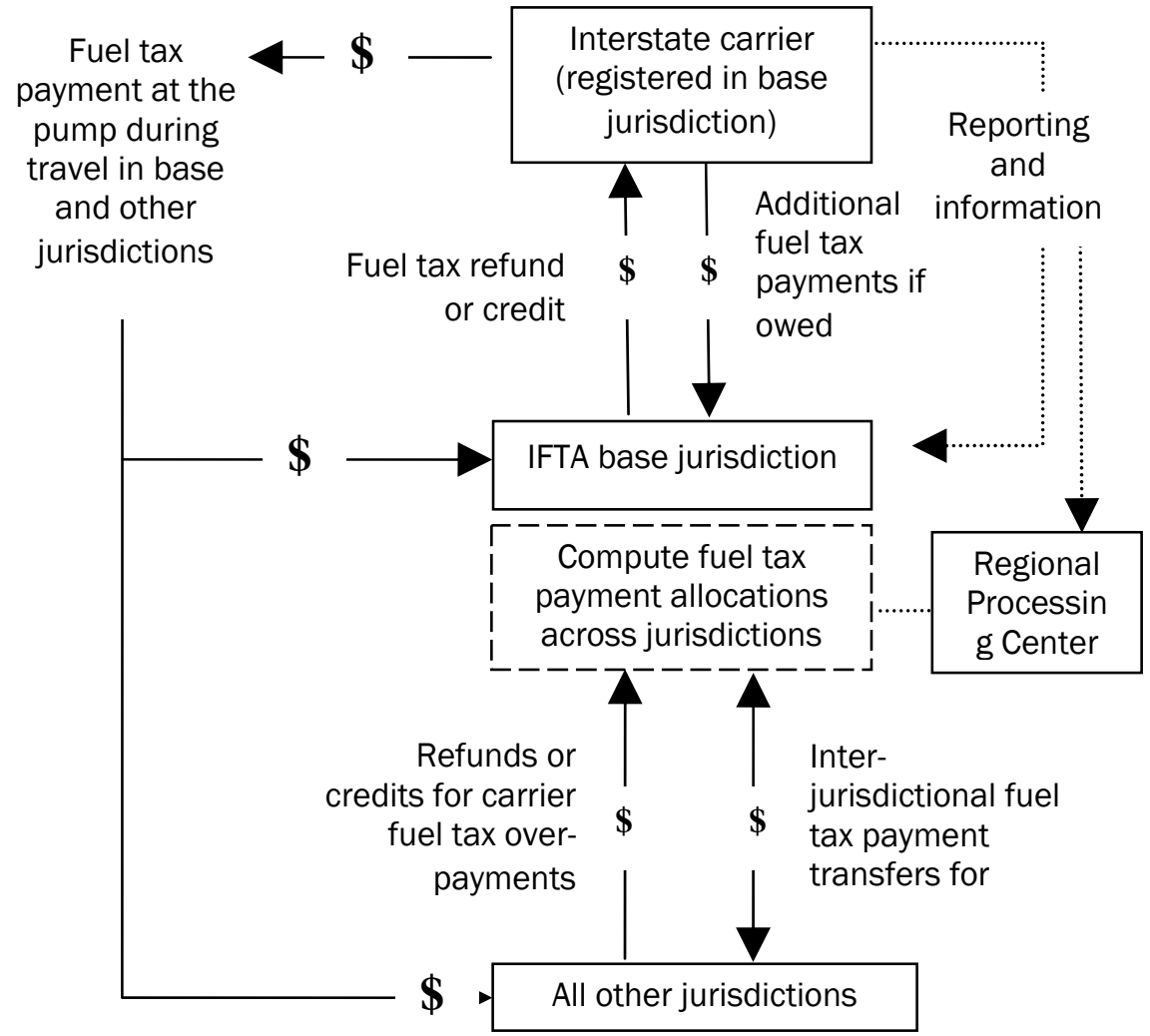


operated the net tax due or receives tax credits from them. This part of the task can be performed in-house by the base state or by a contractor. Fifteen of the U.S. states employ an entity referred to as the Regional Processing Center (RPC) run by New York State as a subcontractor to compute tax burdens and reconcile tax obligations between the carriers and the jurisdictions. ${ }^{3}$

Although the states and provinces can levy different tax rates, IFTA imposes uniformity upon the system in several ways. All IFTA members must accept the same definition of a qualified motor vehicle. IFTA provides a uniform format for the fuel use report along with uniform due dates. It also provides a uniform method for calculating the tax due, and interest on late payments. Further, IFTA creates a uniform system for auditing carriers for compliance. The base jurisdiction is responsible for auditing its licensees on behalf of all member jurisdictions. This, however, does not preclude another jurisdiction from also auditing a licensee.

\section{IFTA, Inc}

IFTA is run by its members (the 48 contiguous states and 10 provinces). In 2009 , each jurisdiction paid $\$ 11,000$ to belong to IFTA. ${ }^{4}$ IFTA's everyday operations are carried out by IFTA, Inc., an administrative unit and information repository located in Tempe, Arizona. IFTA, Inc. is governed by a board of trustees made up of state and provincial fuel tax administrators who represent the 58 member jurisdictions.

IFTA, Inc. does not collect tax payments or returns; that is a responsibility of the member jurisdictions. It does, however, maintain a clearing house that compiles information useful for tax reconciliation as well as information on carrier licensing and suspensions or revocations of licenses. The latter is important, as the fuel tax agreement is enforced by restricting access to other jurisdictions through the revocation of permits (Denison \& Facer, 2005).

IFTA, Inc. conducts yearly business meetings and arranges a number of workshops and training sessions. It also conducts periodic peer reviews of each jurisdiction's adherence to the terms of IFTA, including reviews of the audits of carriers performed by the member jurisdictions. One-fourth of the jurisdictions are reviewed each year. 


\section{IFTA and the Issue of Fuel Tax Evasion}

The advent of IFTA has not eliminated motor fuel tax evasion and the system requires enforcement to ensure compliance. Since the system is based on self-reporting, it is necessary for the states to audit the record-keeping of the carriers. Audits are set up to ensure the accuracy of the reports on fuel use, fleet mileage in each state, and miles per gallon calculations, and the number and type of trucks that a firm has in its fleet. Jurisdictions are required to annually audit three percent of the registered carriers in their state or province. ${ }^{5}$

Carriers can avoid full payment of fuel taxes by making high mileage estimates for travel in low tax rate states. Such reporting could cause some states, especially the high tax states, to get less revenue than they would have if the carrier had reported its actual mileage in each jurisdiction. Ensuring the validity of mileage reporting is, therefore, an important aspect of the IFTA system.

IFTA relies on accurate record keeping by the carriers. To deter fraudulent record keeping, carriers must fear being caught. It is possible that tax evasion is occurring because the states are not conducting a sufficient number of audits to minimize tax avoidance and maximize fuel tax revenues. The positive effect of frequent auditing on tax collections is well-documented. For instance, Eger and Hackbart (2005) found that more frequent auditing, accomplished by increasing the number of auditors employed by a state, appears to increase fuel tax revenues.

\section{IFTA EFFECTIVENESS: THE STATE PERSPECTIVE}

This study focuses on IFTA's effectiveness at three core tasks: (1) fostering cooperation among participating jurisdictions; (2) allocating tax burdens, payments, and revenues among these jurisdictions; and (3) collecting tax revenues and preventing tax evasion.

The core mission of IFTA is to facilitate inter-jurisdictional reconciliation of motor fuel tax payments. For this to occur smoothly, each jurisdiction must communicate effectively with IFTA, Inc. and have trust in the IFTA system as well as trust in the actions of the member jurisdictions. Thus, from the perspective of each jurisdiction, IFTA should encourage inter-jurisdictional cooperation, facilitate effective communication with IFTA, Inc. and be responsive to each jurisdiction's legal, policy, and administrative concerns. If IFTA is 
operating effectively, the jurisdictions are also likely to indicate satisfaction with IFTA, Inc. and with each other's efforts to coordinate and reconcile tax payments.

Effectiveness as a multijurisdictional tax administration system requires successful prevention of tax evasion. This study looks at two indicators of possible tax evasion: (1) the selection of the base state by commercial carriers; and (2) the extent to which carriers are audited for compliance with IFTA rules and assessed additional taxes. IFTA's effectiveness may be diminished if commercial carriers make decisions about their choice of base state according to factors such as vehicle registration fees, fuel tax rates, and audit rates. Because the IFTA system is based on self-reporting, tax evasion may take place through poor record keeping or other carrier reporting errors. The states, therefore, must audit the record-keeping of the carriers to ensure they are complying with IFTA's rules. Selection of carriers to audit, audit stringency, audit results and identified sources of reporting errors are important elements of assessing IFTA's effectiveness in terms of tax compliance or evasion.

\section{Survey of IFTA Officials in the States and Provinces}

Our analysis of IFTA's effectiveness is based on data collected from a 2006 mail survey sent to the official IFTA contact person in each of the IFTA jurisdictions. These IFTA officials manage fuel tax collection at the state level and are strategically positioned to evaluate the overall effectiveness of IFTA. ${ }^{6}$ The survey was mailed to all IFTA jurisdictions in September 2006 with a follow-up survey sent in mid-October. Respondents were given the option of returning the surveys by mail (via pre-paid return envelope), e-mail or fax. Thirtythree of the 58 IFTA states and provinces (57\%) participated in the survey. ${ }^{7}$ The survey findings have been supplemented with other data on motor carrier audits, which was obtained from the IFTA Clearinghouse (www.iftach.org). This data was used to assess the audit performance of IFTA jurisdictions and to assess the representativeness of the sample by comparing the average percent of firms audited in the two types of jurisdictions-those that responded and those that did not. The differences were not statistically significant, with those jurisdictions responding to the survey having audited $2.90 \%$ of motor carriers registered in their jurisdictions, and $2.92 \%$ for non-responders ( $t=-0.113$ ). This suggests that response bias is not a concern in this study. 
The survey was designed to address three broad questions that correspond to the key components of effectiveness. These questions are

(1) Does IFTA effectively foster cooperation among its member jurisdictions?

(2) Does IFTA effectively promote the allocation of tax burdens, payments, and revenues among jurisdictions? and

(3) Does IFTA effectively promote the collection of tax payments and prevention of tax evasion? Each question and subquestions are discussed below. The specific survey questions are listed in Appendix A. Table 1 summarizes survey responses to the questions regarding IFTA effectiveness.

TABLE 1

Survey Responses to Questions Regarding IFTA's Effectiveness

\begin{tabular}{|c|c|c|c|c|c|}
\hline & $\begin{array}{c}\text { Extremely } \\
\text { Ineffective } \\
1 .\end{array}$ & $\begin{array}{l}\text { Somewhat } \\
\text { Ineffective } \\
2 .\end{array}$ & $\begin{array}{l}\text { Somewhat } \\
\text { Effective } \\
3 .\end{array}$ & $\begin{array}{c}\text { Very } \\
\text { Effective } \\
4 .\end{array}$ & $\begin{array}{c}\text { Extremely } \\
\text { Effective } \\
5 .\end{array}$ \\
\hline \multicolumn{6}{|c|}{ Fostering Cooperation } \\
\hline $\begin{array}{l}\text { Effectiveness at } \\
\text { encouraging inter- } \\
\text { jurisdictional trust } \\
\text { and cooperation } \\
(n=30)\end{array}$ & $\begin{array}{c}0 \\
(0 \%)\end{array}$ & $\begin{array}{c}0 \\
(0 \%)\end{array}$ & $\begin{array}{c}5 \\
(16.7 \%)\end{array}$ & $\begin{array}{c}20 \\
(66.7 \%)\end{array}$ & $\begin{array}{c}5 \\
(16.7 \%)\end{array}$ \\
\hline $\begin{array}{l}\text { Satisfaction with } \\
\text { communications } \\
\text { with IFTA, Inc. } \\
(n=32)\end{array}$ & $\begin{array}{c}0 \\
(0 \%)\end{array}$ & $\begin{array}{c}1 \\
(3.1 \%)\end{array}$ & $\begin{array}{c}3 \\
(9.4 \%)\end{array}$ & $\begin{array}{c}22 \\
(68.8 \%)\end{array}$ & $\begin{array}{c}6 \\
(18.8 \%)\end{array}$ \\
\hline $\begin{array}{l}\text { Responsiveness to } \\
\text { jurisdictional } \\
\text { concerns }(n=32)\end{array}$ & $\begin{array}{c}0 \\
(0 \%)\end{array}$ & $\begin{array}{c}2 \\
(6.3 \%)\end{array}$ & $\begin{array}{c}6 \\
(18.8 \%)\end{array}$ & $\begin{array}{c}20 \\
(62.5 \%)\end{array}$ & $\begin{array}{c}4 \\
(12.5 \%)\end{array}$ \\
\hline \multicolumn{6}{|c|}{ Allocating Tax Burdens and Payments } \\
\hline $\begin{array}{l}\text { Effectiveness at } \\
\text { enhancing } \\
\text { equitable tax } \\
\text { collection }(n=33)\end{array}$ & $\begin{array}{c}0 \\
(0 \%)\end{array}$ & $\begin{array}{c}0 \\
(0 \%)\end{array}$ & $\begin{array}{c}4 \\
(12.1 \%)\end{array}$ & $\begin{array}{c}21 \\
(63.6 \%)\end{array}$ & $\begin{array}{c}8 \\
(24.2 \%)\end{array}$ \\
\hline $\begin{array}{l}\text { Satisfaction with } \\
\text { other jurisdictions } \\
\text { in regard to } \\
\text { coordination of tax } \\
\text { netting }(n=31)\end{array}$ & $\begin{array}{c}1 \\
(3.2 \%)\end{array}$ & $\begin{array}{c}3 \\
(9.7 \%)\end{array}$ & $\begin{array}{c}10 \\
(32.3 \%)\end{array}$ & $\begin{array}{c}17 \\
(54.8 \%)\end{array}$ & $\begin{array}{c}0 \\
(0 \%)\end{array}$ \\
\hline
\end{tabular}




\section{Does IFTA Effectively Foster Cooperation among the Participating Jurisdictions?}

The survey asked three questions that pertain to this dimension of effectiveness. These questions are

1. How effective is IFTA in meeting its mission of fostering interjurisdictional trust and cooperation?

2. How satisfied are you with communication with IFTA, Inc.?

3. How responsive has IFTA been to your state's/province's legal, policy, or administrative concerns?

Respondents were overwhelmingly satisfied with IFTA's functioning in terms of inter-jurisdictional trust and cooperation, with 16.7 percent and 66.7 percent of respondents citing IFTA as extremely effective or very effective, respectively (see Table 1). None of the respondents rated IFTA as ineffective in this regard. On a fivepoint scale with 1 representing not at all effective and 5 being extremely effective, the average score on this question was 4.00 or very effective.

For IFTA to foster cooperation between the participating jurisdictions, it must be perceived as being accessible by (and responsive to) its constituents. Concerning accessibility, 66 percent of respondents were very satisfied and ten percent were somewhat satisfied with their communication with IFTA, Inc. None of the respondents expressed dissatisfaction. In regard to responsiveness, thirteen percent and 63 percent of respondents rated IFTA as extremely or very responsive to their jurisdiction's concerns, respectively. The average response for the accessibility question was 4.03 and the average for the responsiveness question was 3.82.

\section{Does IFTA Effectively Promote the Allocation of Tax Burdens, Payments, and Revenues?}

The survey asked the question: In your opinion how effective or ineffective has IFTA been in enhancing your state's ability to collect motor fuel tax revenues equitably? The mean response was 4.12, with 24.2 percent responding that IFTA was extremely effective, 63.6 percent responding it was very effective, and 12.1 percent somewhat effective. 
Another dimension of tax burden, payment, and revenue allocation involves jurisdictions' satisfaction with IFTA's coordination of motor fuel tax revenues reconciliation with other jurisdictions. Survey respondent were asked: How satisfied are you with other states/provinces in regard to the coordination of the netting/reconciliation of motor fuel taxes? Responses to this question were slightly less positive than other questions, as 54.8 percent of respondents were very satisfied and 32.3 percent were somewhat satisfied. The average score was 3.37. Overall, IFTA was viewed as a very effective organization in regard to its prime task of coordinating the collection and allocation of fuel taxes.

\section{Does IFTA Effectively Promote Collection of Tax Payments and Prevention of Tax Evasion?}

To evaluate IFTA's effectiveness at preventing tax evasion, we studied two possible indicators: (1) the choice of base state and (2) the results of motor carrier audits. Regarding the base states, we updated the work of Denison and Facer (2005) who found no evidence that carriers choose low tax states as their base state. In terms of selection of base state, IFTA's effectiveness may be diminished if commercial carriers make their decisions based on such factors as vehicle registration fees, fuel tax rates, and audit rates.

To identify the extent to which IFTA-related factors influenced the number of carriers locating in each base state, we regressed the number of commercial carrier accounts in each state on decal price, registration fee, diesel fuel tax rate, audit rates (measured as the percent of carriers audited annually), audit stringency (measured as the percent of audits that produce assessments), and other state characteristics that could potentially influence trucking activity such as gross state product (GSP), size of the state highway system, and population density. 8 Regression results are presented in Table 2. None of the IFTA-related variables were significant; only GSP was statistically significant (see Table 2 ) at $p<0.0001$. The size of the highway system was marginally significant $(p<0.05)$. This suggests that carriers are not choosing low tax and low registration fee states as their base jurisdiction to avoid fees and taxes. Nor are they selecting the base jurisdiction with lower audit rates and less stringent audits. Instead, the number of carrier accounts in the 
TABLE 2

Regression Results

\begin{tabular}{|l|c|c|}
\hline $\begin{array}{c}\text { Dependent Variable: Number of } \\
\text { Commercial Carrier Accounts }\end{array}$ & $\begin{array}{c}\text { Coefficient } \\
\text { (Std. Error) }\end{array}$ & t-value \\
\hline Audit Percentage & $58.42(394.38)$ & 0.15 \\
\hline Audit Stringency & $3.33(20.43)$ & 0.16 \\
\hline Decal Cost & $-48.42(60.13)$ & -0.81 \\
\hline Registration Fee & $0.62(0.95)$ & 0.66 \\
\hline Diesel Fuel Tax Rate & $-12.16(66.72)$ & -0.18 \\
\hline Gross State Product & $0.0081^{* *}(0.0015)$ & 6.08 \\
\hline Population Density & $2.96(2.17)$ & 1.37 \\
\hline Size of Highway System & $0.054(0.020)$ & 2.65 \\
\hline $\mathrm{N}$ & 47 & \\
\hline Adjusted R 2 & 0.684 & \\
\hline
\end{tabular}

Notes: ${ }^{* * *} p<0.0001$. The independent variables were checked for multicollinearity. The variance inflation factor ranged from 1.11 to 1.43 (the average was 1.30), indicating that multicollinearity is not a concern.

jurisdictions appears to be driven by economic activity (measured by GSP) and the extensiveness of the highway system. This is in line with the argument made by Denison and Facer (2005) who concluded that there are no "grievous distortions in the distribution of base state accounts" (p. 598) associated with IFTA.

IFTA audit procedures call for each base jurisdiction to audit three percent of its registered carriers. The mean audit percentage in 2007 was 2.9 percent, so, on average, the jurisdictions are in rough compliance with the requirement. Survey respondents were asked how they selected carriers for audits. Most said they used random sampling in accord with the requirements of the IFTA audit manual. However, many also said they looked for indicators of possible tax avoidance. Kentucky, for example said that, in addition to random checks, audited firms are selected from indicators such as low miles for the number of decals (trucks), miles per gallon problems, and fuel credit issues. Idaho also mentioned a combination of methods: "Idaho uses random sampling for all sizes of carriers to meet the IFTA audit stratification requirements-plus we select non-complying licensees, re-audits for compliance reasons, or licensees who 
consistently file inaccurate quarterly returns." Several respondents mentioned such indicators of reporting inaccuracy as constant miles per gallon or high miles per gallon. Nova Scotia said it selected large carriers with bulk fuel purchases for audits.

Review of IFTA records from the IFTA Annual Reports from 2000 to 2008 suggest that states vary in the stringency of their audits. On average, over the eight year period, 73 percent of audits resulted in assessments. This percentage has increased from 71 percent in 2000 to 77 percent in 2008, suggesting that either more carriers are misreporting their fuel tax liabilities and/or that states are becoming more strict in conducting their audits and applying assessments.

There is also significant variation across the jurisdictions in terms of the results of their audits. lowa, for example, has the lowest percentage of audits resulting in assessments, with only 27 percent of audits yielding assessment for the period between 2000 and 2008. In comparison, South Carolina possibly has the most stringent audit process, with 97 percent of audits resulting in assessments.

The survey included questions regarding the nature of assessments resulting from the audits. IFTA records show that in 2004 , the vast majority of audits (74\%) found deficiencies such as problems with the carrier's records and tax payment and other errors that often results in an assessment for taxes not paid. Survey respondents were asked what percentage of these audits resulted in assessment and subsequent collection of additional motor fuel tax revenue. The average response was 71 percent. Thus, approximately 53 percent of all audits $(0.74 \times 0.71)$ generate additional fuel tax revenue.

The survey also attempted to identify the sources of error that lead to the audit assessments. The most common error is underreporting of mileage-the average estimate of the percent of errors due to underreporting was 57 percent. The second most common was the other category-31 percent. This category included such errors as missing fuel reports and lack of records. Misallocation of mileage to low tax rate states (14\%), misreporting of off-road or tax exempt use (7\%) and late reporting (5\%) were the other sources of errors identified by respondents; note that these error categories are not mutually exclusive, and therefore the total percent of the types of errors exceed 100 percent. From the responding states' estimates, it 
seems likely that the misallocating of mileage to low tax-rate states is a continuing problem. Indeed, this is reported to be a greater problem than misreporting of off-road or tax exempt use. While the underreporting of mileage is a problem for all jurisdictions, the misallocation of mileage may produce substantial losses for the high tax rate jurisdictions, a possibility suggested by one respondent.

\section{CONCLUSION}

IFTA provides an example of a tax system that facilitates the administration of taxes across multiple jurisdictional boundaries. It is particularly interesting because it involves not only the American states but the Canadian provinces as well. Furthermore, the federal mechanism through which IFTA was implemented has important repercussions for other types of taxes. While the motor fuel tax can be thought of as a "simple" tax involving only the payment of taxes on the purchase of motor fuels, this simplicity allows for a study of IFTA's effectiveness that provides clear and straightforward lessons of what constitutes an effective multijurisdictional tax administration model.

As we illustrate in this study, IFTA appears to be effective as a model for administering the diesel fuel tax across multiple jurisdictions in the U.S. and Canada. IFTA has been found to reduce the tax compliance burden on interstate commercial carriers. It is also effective as a mechanism for fostering coordination and cooperation among participating jurisdictions in addition to ensuring perceived fairness and equity in the collection and distribution of diesel fuel tax revenues.

Our findings are consistent with Denison and Facer's study (2005) in regard to the choice of jurisdiction. However, given the percent of audits that results in increased revenue collection, the success of IFTA in reducing tax evasion remains unclear. Tax evasion due to sloppy or deceitful record-keeping seems to be overly prevalent.

It is possible that tax evasion is occurring because the states are not conducting a sufficient number of audits to minimize tax avoidance and maximize fuel tax and registration fee revenues (Eger $\&$ Hackbart, 2005). But the finding that they are auditing 2.9 percent of carriers annually suggests that other reforms, such as penalties for inadequate record-keeping may be needed. Taxpayer active systems 
benefit from ways to reduce the temptation or ability of taxpayers to falsify the relevant records (Mikesell, 2007). Denison and Facer (2005) suggested that fuel tax enforcement can improve with the use of trip recorders and electronic vehicle management systems. These can be used to verify the reported miles driven in a state without imposing additional audit costs on the taxpayer. But their utility for improved record keeping and auditing has yet to be established.

At this time, base jurisdictions impose interest on late tax payments. The base jurisdiction has the authority to impose fines, but these vary in size and records were not available for the average size of the assessment or fine. Clearly, research is needed on the frequency, size, and effectiveness of the fines. It may be the case that more frequent or larger fines would reduce the percent of audits that lead to an assessment.

\section{Implications for Other Taxes}

The assessment and collection of state taxes have become more complicated as multi-state and multi-national businesses and corporations increasingly dominate the economic activity of the states. Determining what portion of a multi-state or multi-national corporation's business activity is subject to a state's corporate income tax, sales tax, or property tax requires data and information as well as multijurisdictional tax administration efforts-all of which may exceed an individual state's capacity. Such tax collection processes are further complicated by the limited authority given to states for tax collections from out-of-state firms.

This study's findings suggest that the experience of the states with IFTA may be relevant for other inter-state or multijurisdictional taxes, such as taxing remote (catalog and internet) sales. In fact, IFTA was established and became instituted "in circumstances that are similar in many respects to those that surround the remote sales controversy today" (Pitcher, 2001, p. 887).

IFTA appears to handle tax netting and reconciliation with efficiency and generates few if any conflicts between the states. The creation of an oversight and coordinating organization comparable to IFTA, Inc seems feasible for sales and other taxes. The base state concept too seems directly applicable. Large as well as small retailers could register in a base state and keep records of their transactions 
from each store or location of sale. As with IFTA, the base state could handle auditing.

As Pitcher (2001), argued, some form of federal involvement will likely be necessary to ensure uniformity of reporting and enforcement, because the federal government has constitutional authority over the regulation of interstate commerce. The states may need federal legislative authorization to require out-of-state businesses and corporations to collect taxes on their behalf. Once federal authorization is obtained, the IFTA experience suggests remaining legal issues can be resolved with little conflict between the states.

However, the IFTA experience does not offer any lessons for how to address uniformity of taxable items across the multiple jurisdictions. IFTA required uniformity in the definition of the motor fuel tax that is taxable, but obtaining agreements among the states and localities on the definition of the many taxable sales items will be a challenge. In this regard, the sales tax is significantly more complicated than the motor fuel tax. Furthermore, as our findings suggest, IFTA has not been sufficiently effective as a mechanism for reducing tax evasion. However, given that remote sales occur almost entirely by credit card or check, it may be more difficult for venders to conceal their sales tax obligations than it appears to be for carriers to keep inaccurate records on mileage in each jurisdiction. Future research on IFTA's response to the problem of inaccurate record keeping and underpayment of taxes could provide important insights for the streamlined sales tax effort to create a workable system for taxing remote sales (catalog and internet).

There has also been much discussion about the inadequacy of the fuel tax as a source of revenue for transportation, both at the federal and state levels. Several options have been proposed as remedies to solve diminishing fuel tax revenues, including charging fees for vehicle miles traveled (VMT) and congestion pricing (Rufolo \& Bertini, 2003). As a substitute for the fuel tax, the VMT fee, which is a distance-based user charge, seems to have gained traction over the past few years (Forkenbrock, 2005).

A VMT fee pilot system implemented in Oregon determined its feasibility as a source of transportation-related revenues for states (Kim et. al, 2008). Several states are currently participating in the Road User Charge Study, a national evaluation of a distance- or 
mileage-based road user charge system (Kuhl, 2009). The VMT fee has also been at the forefront of discussions regarding transportation finance at the federal level (National Surface Transportation Infrastructure Financing Commission, 2009)

The results of this study suggest that IFTA, as an administrative and coordinating mechanism, will work under a VMT fee system. In fact, a move to distance-based user charges will simplify the system. Commercial carriers will continue to report their mileage and the distribution of that mileage across the different jurisdictions, in the same way they currently report under the IFTA system. However, carriers would no longer need to submit fuel tax payment information or estimate their vehicle fuel efficiency.

\section{ACKNOWLEDGMENTS}

This paper is based on research funded by the Community Transportation Innovation Academy at the Kentucky Transportation Center, University of Kentucky. We would like to thank Dr. Merl Hackbart and the anonymous reviewers for their feedback.

\section{NOTES}

1. Moreover, IFTA is not a federal program. IFTA has been categorized as a hybrid program by the National Conference of State Legislatures-a combination of interstate compact, administrative agreement among states, and contract between states and taxpayers. In this respect, IFTA is unique. Its legal basis is through the concept of the interstate compact, which is permissible under Article 1, Section 10, Clause 3 of the U.S. Constitution (Sundeen \& Goehring, 1999).

2. FHWA Region 8 includes Colorado, Montana, North Dakota, South Dakota, Utah, Wyoming, and the Canadian provinces of Alberta, Manitoba, and Saskatchewan.

3. The RPC has two service levels. The first is the "complete package" of services. A jurisdiction employing the RPC supplies to the RPC all the demographic information for IFTA taxpayers (the carriers) based in their jurisdiction. In addition to the demographic information, data is kept on taxpayer status (active, inactive, suspended, or revoked), registration type, fuel types 
used, jurisdictions traveled, etc. The other RPC option available to jurisdictions is the funding -only portion. This option allows a jurisdiction to process returns on their own platform and, via a RPC data entry screen, enter their liability amounts for each IFTA jurisdiction prior to the final netting deadline.

4. In 2006 , the year the IFTA survey was conducted, the fee was $\$ 10,000$.

5. The IFTA Articles of Agreement states that an audit means the following: (1) The physical examination of the source documentation of the licensee's operations whether in detail or on a representative sample basis; (2) The evaluation of the internal controls of the licensee's accounting system and operations; and (3) The accumulation of sufficient competent evidential matter to afford a reasonable basis for determining whether or not there are any material differences between actual and reported operations for each affected jurisdiction in accordance with the provisions of the IFTA and all affected jurisdictions' fuel use tax laws.

6. These IFTA officials were organizationally located primarily in the respective state transportation agency $(38 \%)$ or in the state revenue agency (57\%). The survey asked respondents about their roles and responsibilities and experiences, and there was not significant variation. IFTA, Inc. designates one person from each IFTA state/province as the IFTA official. We believe that it is reasonable to assume that the IFTA contact persons surveyed are equally competent and knowledgeable about IFTA policies and operations in their respective states.

7. Responding Canadian provinces were Alberta, Manitoba, New Brunswick, Nova Scotia, Prince Edward Island, Quebec, Saskatchewan, Ontario, Labrador, Yukon, and responding U.S. States were Alabama, Arizona, Arkansas, California, Colorado, Connecticut, Delaware, Florida, Georgia, Idaho, Illinois, Indiana, lowa, Kansas, Kentucky, Louisiana, Maine, Maryland, Massachusetts, Michigan, Minnesota, Mississippi, Missouri, Montana, Nebraska, Nevada, New Hampshire, New Jersey, New Mexico, New York, North Carolina, North Dakota, Ohio Oklahoma, Oregon, Pennsylvania, Rhode Island, South Carolina, South Dakota, Tennessee, Texas, Utah, Vermont, Virginia, Washington, West Virginia, Wisconsin, and Wyoming. Comparison of 
respondents and non-respondents on the basis of the number of carriers, audit and assessment rates, GSP, and population were not statistically significant.

8. We also included geographic size and number of manufacturing and transportation/warehousing establishments as independent variables but they were not statistically significant in the model and were removed from the final model due to concerns regarding degrees-of-freedom.

\section{REFERENCES}

Denison, D., \& Facer, R. (2005). “Interstate Tax Coordination: Lessons from the International Fuel Tax Agreement." National Tax Journal, 58 (3): 591-603.

Due, J. F. \& Mikesell, J. L. (1994). Sales Taxation, State and Local Structures and Administration. Washington, DC: Urban Institute Press.

Eger, R., \& Hackbart, M. (2005). "Road Fund Tax Compliance: An Analysis of Enhancement Strategies." Public Budgeting and Finance, 25 (1): 66-103.

Forkenbrock, D. J. (2005). "Implementing a Mileage-based Road User Charge." Public Works Management and Policy, 10: 87-100.

Griffin, G., Lantz, B., Rodriguez, J., \& Titus, M. (1994). Motor Carrier Industry Perceptions of IFTA and IRP MTC Report No. 95-45. Fargo, ND: Upper Great Plains Transportation Institute.

Intermodal Surface Transportation Efficiency Act of 1991 (1991). Pub. L. No. 102-240, § 4008(g)(1), 105 Stat. 2154.

Kuhl, J. G. (2009). Project Overview: National Evaluation of a Mileagebased Road User Charge. [Online]. Available at http://ppc.uiowa.edu/dnn4/TransportationbrPolicyResearch/Roa dUserChargeStudy/tabid/65/Default.aspx. [Retrieved June 16, 2009]

Mikesell, J. L. (2007). Fiscal Administration: Analysis and Applications for the Public Sector. Pacific Grove, CA: Thomson Wadsworth.

National Surface Transportation Infrastructure Financing Commission. (2009). Paying Our Way: A New Framework for 
Transportation Finance. Washington, DC: U.S. Department of Transportation.

Pitcher, R. (2001). "The International Fuel Tax Agreement: Are there Lessons here for Sales and Use Taxation." State Tax Notes, 25: 887-91.

Rufolo, A. M., \& Bertini, R. L. (2003). "Designing Alternatives to State Motor Fuel Taxes." Transportation Quarterly, 57: 33-46.

Sundeen, M., \& Goehring, J. B. (1999). IFTA Legislation and State Constitutional Provisions Project: Final Report. Denver, CO: National Conference of State Legislatures.

\section{APPENDIX A \\ Survey Questions}

1. Overall, how effective is IFTA in meeting its mission of fostering interjurisdictional trust and cooperation?

\begin{tabular}{ccccc}
$\begin{array}{c}\text { Extremely } \\
\text { Ineffective }\end{array}$ & $\begin{array}{c}\text { Somewhat } \\
\text { Ineffective }\end{array}$ & $\begin{array}{c}\text { Somewhat } \\
\text { Effective }\end{array}$ & $\begin{array}{c}\text { Very } \\
\text { Effective }\end{array}$ & $\begin{array}{c}\text { Extremely } \\
\text { Effective }\end{array}$ \\
1 & 2 & 3 & 4 & 5 \\
\hline
\end{tabular}

2. How satisfied are you with communication with IFTA, Inc.?

\begin{tabular}{ccccc} 
Extremely & Somewhat & Somewhat & Very & Extremely \\
Dissatisfied & Dissatisfied & Satisfied & Satisfied & Satisfied \\
1 & 2 & 3 & 4 & 5 \\
\hline
\end{tabular}

3. Overall, how responsive has IFTA been to your state's/province's legal, policy, or administrative concerns?

\begin{tabular}{ccccc} 
Extremely & Somewhat & Somewhat & & \\
Unresponsiv & Unresponsiv & Responsiv & Very & Extremely \\
e & $e$ & $e$ & Responsive & Responsive \\
1 & 2 & 3 & 4 & 5 \\
\hline
\end{tabular}

4. In your opinion, how effective or ineffective has IFTA been in enhancing your state's ability to collect motor fuel tax revenues equitably?

\begin{tabular}{ccccc} 
Extremely & Somewhat & Somewhat & Very & Extremely \\
Ineffective & Ineffective & Effective & Effective & Effective \\
1 & 2 & 3 & 4 & 5 \\
\hline
\end{tabular}


5. How satisfied are you with other states/provinces in regard to the coordination of the netting (reconciliation) of motor fuel taxes?

$\begin{array}{ccccc}\text { Extremely } & \text { Somewhat } & \text { Somewhat } & \text { Very } & \text { Extremely } \\ \text { Dissatisfied } & \text { Dissatisfied } & \text { Satisfied } & \text { Satisfied } & \text { Satisfied } \\ 1 & 2 & 3 & 4 & 5\end{array}$

\begin{tabular}{ccccc}
1 & 2 & 3 & 4 & 5 \\
\hline$\square$ & $\square$ & $\square$ & $\square$ & $\square$
\end{tabular}

6. What strategies for conducting IFTA audits does your state/province follow?

7. What was the approximate percent of these assessments that resulted in collections of motor fuels tax revenue? $\%$

8. Audit assessments are levied for several reasons. Please estimate the percent of IFTA audit assessments levied for the following reasons.

Underreporting mileage

Percent

Late reporting

Misallocating mileage to low tax-rate states Misreporting of off-road/tax-exempt use Other

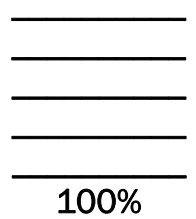

